\title{
IMPLEMENTASI PERDA NO. 09 TAHUN 2014 TENTANG PENGELOLAAN PASAR RAKYAT, PUSAT PERBELANJAAN, DAN TOKO SWALAYAN
}

\author{
Virna Museliza dan Yessi Nesneri \\ Fekonsos UIN Suska Riau, Jalan Raya Pekanbaru - Bangkinang, Pekanbaru 28293
}

\begin{abstract}
Implementation of Regional Regulation No. 09 of 2014 concerning Public Market Management, Shopping Centers and Supermarkets. This study aims to analysis of implementation of Pekanbaru City Regional Regulation number 09 of 2014 concerning the management of the people's markets, shopping centers and supermarkets and obstacles implementation. This research uses descriptive research with a qualitative approach. The results of the analysis of the Implementation of Pekanbaru City Regulation No. 09 of 2014 there are 4 (four) research indicators, namely in the Arrangement, the aspect of determining the location is in accordance with the Local Spatial Plan; Empowerment is based on the vision and mission and conducts special training for managers in terms of training to maintain market cleanliness and security, to remain hygienic and how to manage traders to sell in an orderly manner in the kiosk and create professional management and coaching, improve market traders' competence by training on procedures for serving buyers and socializing; while Supervision does not yet refer to Pekanbaru City Regulation number 09 of 2014 concerning the management of community markets, shopping centers and supermarkets due to not yet operating optimally, is being carried out renovations, Pekanbaru City Health Office has not carried out direct inspections and the Supervisory report has not been reported to Mayor and DPRD. Constraints in 1). Arrangement, Narrow market location; 2). Empowerment, it is difficult to conduct disciplinary guidance to traders; 3). Coaching, difficulty in obtaining alternative sources of funding, and ineffectiveness of the results of socialization; and 4). Supervision, ineffectiveness of supervision carried out, people who have kiosks / kiosks are leased to other traders at expensive rental prices, supervision of withdrawal of traders' fees.
\end{abstract}

\begin{abstract}
Abstrak: Implementasi Perda No. 09 Tahun 2014 Tentang Pengelolaan Pasar Rakyat, Pusat Perbelanjaan, dan Toko Swalayan. Penelitian ini bertujuan untuk menganalisis implementasi Peraturan Daerah Kota Pekanbaru No. 09 tahun 2014 tentang Pengelolaan Pasar Rakyat, Pusat Perbelanjaan Dan Toko Swalayan dan kendala-kendala implementasinya. Penelitian ini menggunakan jenis penelitian deskriptif dengan pendekatan kualitatif. Hasil penelitian Analisis Implementasi Peraturan Daerah Kota Pekanbaru nomor 09 tahun 2014 ada 4 (empat) indikator penelitian yaitu Pada Penataan, segi penentuan lokasi sudah sesuai dengan Rencana Umum Tata Ruang Setempat; Pemberdayaan sudah berdasarkan visi dan misi dan mengadakan pelatihan khusus kepada pengelola dalam hal pelatihan untuk menjaga kebersihan dan keamanan pasar, agar tetap higienis dan cara mengelola pedagang agar berjualan dengan tertib dalam kios serta tercipta manajemen yang profesional dan Pembinaan, meningkatkan kompetensi pedagang pasar yakni dengan melakukan pelatihan tentang tata cara melayani pembeli dan telah melakukan sosialisasi; sedangkan Pengawasan belum mengacu kepada Peraturan Daerah Kota Pekanbaru nomor 09 tahun 2014 tentang pengelolaan pasar rakyat, pusat perbelanjaan dan toko swalayan dikarenakan belum beroperasinya secara optimal, sedang dilaksanakan renovasi, Dinas Kesehatan Kota Pekanbaru belum melaksanakan inspeksi secara langsung dan laporan hasil Pengawasan belum di laporkan kepada Walikota dan DPRD. Kendala pada 1). Penataan, Sempitnya lokasi pasar; 2). Pemberdayaan, sulitnya melakukan pembinaan disiplin kepada para pedagang;3). Pembinaan, sulitnya mendapatkan sumber alternatif pendanaan, serta tidak efektifnya hasil sosialisasi; dan 4). Pengawasan, tidak efektifnya pengawasan yang dilakukan, masyarakat yang punya kios/los disewakan kepada pedagang lain dengan harga sewa yang mahal, pengawasan dalam penarikan uang retribusi pedagang.
\end{abstract}

Kata Kunci: Pasar higienis madani, penataan, pemberdayaan, pembinaan dan pengawasan.

\section{PENDAHULUAN}

Status kesehatan suatu populasi sangat ditentukan oleh kondisi tempat-tempat dimana orang banyak beraktivitas setiap harinya dan juga ketersediaan layanan kesehatan. Pasar merupakan salah satu tempat dimana orang beraktivitas setiap harinya dan berperan sangat penting dalam pemenuhan kebutuhan, terutama pasar tradisional bagi golongan masyarakat menengah ke bawah. Pada saat yang sama, 
pasar juga dapat menjadi jalur utama untuk penyebaran penyakit seperti penyakit kolera dan flu burung.

Pasar memiliki posisi yang sangat penting untuk menyediakan pangan yang aman dan pasar tersebut dipengaruhi keberadaan produsen hulu (penyedia bahan segar), pemasok, penjual, konsumen, manajer pasar, petugas yang berhubungan dengan kesehatan dan tokoh masyarakat. Oleh karena itu, komitmen dan partisipasi aktif para stake holder dibutuhkan untuk mengembangkan pasar sehat. Pasar sehat adalah kondisi pasar yang bersih, aman, nyaman, dan sehat yang terwujud melalui kerjasama seluruh stakeholder terkait dalam menyediakan bahan pangan yang aman dan bergizi bagi masyarakat.

Di Indonesia terdapat sekitar 13.450 pasar tradisional dengan 12,6 juta pedagang kecil pada tahun 2007, setiap tahunnya pasar tradisional menyusut 8\% sedangkan pasar modern di Indonesia tumbuh 31,4\%, sehingga tersisa 9.950 pasar tradisional pada tahun 2011 “Jika kondisi tersebut dibiarkan, ribuan bahkan jutaan pedagang kecil akan kehilangan mata pencahariannya. Pasar tradisonal mungkin akan tenggelam”, ungkap Deputi Produksi dan Pemasaran, Kemkop dan UKM, I Wayan Dipta pada tanggal 26 Pebuari 2016. Pasar modern dikelola secara professional, sementara di sisi lain pasar tradisonal masih berkutat dengan permasalahan klasik seperti pengelolaan yang kurang professional dan ketidaknyamanan berbelanja serta hampir semua produk yang dijual di pasar tradisional seluruhnya dapat ditemui dipasar modern khususnya hypermarket.

Berbelanja di pasar tradisional masih menjadi kegiatan rutin sebagian besar masyarakat Indonesia. Namun sayang, pengalaman belanja di pasar tradisional tidak selalu menyenangkan. Pasalnya, sarana fisik di sebagian besar pasar tradisional kurang mendukung. Seperti lorong kios yang sempit, minim penerangan dan becek. Membangun pasar tidaklah mudah. Revitalisasi pasar memakan biaya yang tinggi. Selain itu di beberapa tempat pembangunan pasar sering dianggap memarginalisasi pedagang lama karena pedagang ditarik retribusi yang lebih besar. Akibatnya bukan peningkatan kesejahteraan yang didapat, bahkan beberapa pedagang lama tersingkir karena tidak sanggup membayar retribusi.

Data menyebutkan hanya ada 1 (satu) pasar higenis madani dari 7 (tujuh) pasar tradisional yang dikelola oleh Pemerintah Kota Pekanbaru menandakan bahwa banyak pasar yang akan direvitalisasi. Pasar rakyat higienis madani merupakan pasar yang dirancang sebagai pusat perdagangan dengan standar mutu produk sesuai dengan syarat kesehatan, kebersihan, higienitas bahan pangan dan syarat sanitasi lingkungan terawat serta menjunjung tinggi norma dan peradaban. Seperti definisi higienis ialah kondisi lingkungan yang bersih dan sehat yang dilakukan dengan cara mematikan atau mencegah hidupnya jasad renik pathogen untuk menjaga kesehatan manusia. Serta madani artinya yang menjunjung tinggi nilai, norma, hukum yang ditopang oleh penguasaan iman, ilmu, dan teknologi yang berperadaban.

Pemerintah Kota Pekanbaru melaksanakan revitalisasi pasar tradisonal yaitu Pasar Rakyat Teratai Higienis Madani Kecamatan Senapelan berdasarkan Tahun Anggaran 2015 sebagai panduan untuk Pasar Tradisonal lain agar dapat menciptakan pasar yang sehat dan bersih. Dalam Penilaian Pasar Teratai Higienis Madani Kecamatan Senapelan Pemerintah Kota Pekanbaru itu sehat dan bersih yang menjadi acuan adalah berdasarkan Kepmenkes Nomor 519 Tahun 2008 mengenai Lokasi, Bangunan, Perilaku hidup bersih dan sehat, Keamanan dan Fasilitas Lain.

Gedung Pasar Rakyat Teratai Higienis Madani Kecamatan Senapelan merupakan Gedung SDN 019 yang kegiatan mengajarnya dipindahkan dengan alasan karena lokasinya merupakan lokasi pasar. Pasar Rakyat Teratai Higienis Madani Kecamatan Senapelan direvitalisasi agar masyarakat ketika akan berbelanja lebih nyaman, bersih, tidak berbau dan tertata rapi dimana bangunannya dicat, lantainya berkeramik dan memiliki atap penutup serta timbangannya sudah benar, cara pemotongan dan pencucian sudah sesuai dengan syariat Islam serta lokasi di dalam pasar yang 
luas sehingga antara pembeli satu dengan pembeli lainnya tidak bersentuhan.

Akan tetapi apa yang diinginkan pemerintah dengan adanya Pasar Rakyat Teratai Higienis Madani Kecamatan Senapelan tidak tercapai karena pedagang menempati los dan kiosnya selama 3 (tiga) bulan karena los dan kiosnya kecil serta tidak mencukupi untuk menampung semua pedagang yang ada. Serta asumsi masyarakat semakin bagus dan bersih pasarnya maka akan semakin mahal hargaharganya, dan masyarakat sudah terbiasa berbelanja dengan mudah tampa turun dari kendaraannya. Jumlah pedagang yang terdaftar sebagai pengguna kios atau los Pasar Rakyat Teratai Higienis Madani Kecamatan Senapelan di Kota Pekanbaru adalah 150 Pedagang sedangkan pedagang yang jualan di pinggir jalan teratai adalah sekitar 350 lebih.

Penelitian ini bertujuan menganalisis implementasi Peraturan Daerah Kota Pekanbaru Nomor 09 Tahun 2014 tentang Pengelolaan Pasar Rakyat, Pusat Perbelanjaan dan Toko Swalayan dan kendala-kendala dalam implementasinya.

\section{METODE}

Penelitian ini dilakukan Dinas Perindustrian dan Perdagangan Kota Pekanbaru serta Dinas Kesehatan Kota Pekanbaru. Data yang digunakan dalam penelitian ini dikumpulkan dengan cara observasi, wawancara, dan dokumentasi. Informan adalah orang yang dianggap mengetahui tentang apa yang diharapkan dari penelitian yang dilakukan. Penentuan sumber data pada orang yang diwawancarai dilakukan secara purposive yaitu dipilih dengan pertimbangan dan tujuan tertentu.

\section{HASIL DAN PEMBAHASAN}

\section{Implementasi Perda Nomor 09 Tahun 2014}

Untuk menganalisis Peraturan Daerah

Kota Pekanbaru Nomor 09 Tahun 2014 digunakan 4 (empat) indikator yang dijadikan alat ukur dalam pelaksanaannya.

\section{Penataan}

Berdasarkan Peraturan Daerah Kota Pekanbaru Nomor 09 tahun 2014, Penataan adalah upaya yang dilakukan oleh Pemerintah Daerah untuk mengatur dan menata keberadaan dan pendirian Pasar Rakyat, Pusat Perbelanjaan dan Toko Swalayan di suatu daerah agar masing-masing berkembang secara serasi, saling menguntungkan dan saling memperkuat.

Pada dasarnya penataan pasar rakyat Teratai Higienis Madani Kecamatan Senapelan di Kota Pekanbaru jika dilihat dari proses pembangunannya yakni dari segi penentuan lokasi sudah sesuai dengan Rencana Umum Tata Ruang Setempat, serta tidak terletak pada daerah rawan bencana alam, tidak pada daerah kecelakaan atau daerah jalur pendaratan penerbangan, termasuk sempadan jalan, serta tidak terletak pada daerah bekas tempat pembuangan akhir sampah atau bekas lokasi pertambangan, dan mempunyai batas wilayah yang jelas, antara pasar dan lingkungannya.

Pada penataan atas keberadaan dan pendirian pasar rakyat sudah sesuai dengan Peraturan Daerah Kota Pekanbaru nomor 09 tahun 2014 dimana Pasar Rakyat Rakyat Teratai Higienis Madani Kecamatan Senapelan di Kota Pekanbaru berdampingan dengan Pasar Kodim, masing-masing pasar saling menguntungkan dan saling memperkuat. Dalam hal Penataan Bangunan yang dilihat dari renovasi yang dilakukan, secara umum sudah dilakukan penataan Ruang Kantor Pengelola, penataan ruang dagang, penataan tempat penjualan bahan pangan dan makanan, penataan area parkir, kontruksi, tangga, ventilasi, pintu serta sudah terdapat pencahayaan yang cukup baik di dalam pasar (hal ini terlihat dari pembangunan yang saat ini sedang berlangsung).

Selain itu dalam hal sanitasi, di dalam Pasar Rakyat Teratai Higienis Madani sudah di rancang untuk penyediaan air bersih, kamar mandi dan toilet, bagian pengelola sampah, Drainase, Tempat Cuci Tangan, serta apabila sudah resmi beroperasi akan di check secara berkala kualitas makanan dan bahan pangan yang di jual di pasar, yakni melalui kerja sama dengan Dinas Kesehatan Kota Pekanbaru. Namun, pelaksanaan dari Dinas Kesehatan 
Kota Pekanbaru yang seharusnya melakukan inspeksi rutin untuk menilai sehat atau tidaknya pasar belum dilaksanakan, karena belum beroperasinya Pasar Rakyat Teratai Higienis Madani Kecamatan Senapelan Kota Pekanbaru. Dan untuk pengukuran baik buruknya pelaksanaan, belum bisa dilakukan. Sebab, belum beroperasinya Pasar Rakyat Teratai Higienis Madani Kecamatan Senapelan Kota Pekanbaru.

\section{Pemberdayaan}

Pemberdayaan adalah upaya Pemerintah Daerah dalam melindungi Pasar Rakyat agar tetap eksis dan mampu berkembang menjadi suatu usaha yang lebih berkualitas baik dari aspek manajemen dan fisik/tempat agar dapat bersinergi dengan Pusat Perbelanjaan dan Toko Swalayan. Berdasarkan hasil wawancara dan pengamatan tentang apa upaya Pemerintah Daerah dalam meningkatkan profesionalisme pengelola maka dapat diketahui bahwa pada dasarnya pemerintah telah berupaya untuk meningkatkan profesionalisme pengelola, yakni dengan menetapkan visi dan misi, Standar Operasional Prosedur (SOP), pembentukan struktur organisasi, dan uraian tugas yang jelas, serta mengadakan pelatihan khusus kepada pengelola yakni dalam hal pelatihan untuk menjaga kebersihan dan keamanan pasar, agar tetap higienis dan cara mengelola pedagang agar berjualan dengan tertib dalam kios serta tercipta manajemen yang profesional.

Pemerintah daerah telah berupaya melindungi Pasar Rakyat agar tetap eksis dan mampu berkembang menjadi suatu usaha yang lebih berkualitas, baik dari aspek manajemen, maupun fisik atau tempat agar dapat bersinergi dengan pusat perbelanjaan dan toko swalayan. Yakni melalui peningkatan profesionalisme pengelola, peningkatan kompetensi pedagang pasar, peningkatan kualitas dan pembenahan sarana fisik pasar. Dengan mengacu kepada Peraturan Daerah Kota Pekanbaru Nomor 09 Tahun 2014, walaupun pada hakekatnya untuk permodalan, promosi, dan pemasaran tidak terdapat peran pemerintah akibat tidak ter- sedianya anggaran untuk hal tersebut, namun, hal ini bisa di lakukan oleh pedagang melalui pemanfaatan hasil pelatihan dalam rangka peningkatan kompetensi pedagang sebagai hasil timbal balik dari yang program pemerintah.

\section{Pembinaan}

Pembinaan adalah upaya yang dilakukan oleh Pemerintah Daerah untuk membina keberadaan pasar rakyat dan pendirian Pusat Perbelanjaan dan Toko Swalayan. Berdasarkan hasil wawancara dan pengamatan yang dilakukan dapat disimpulkan bahwa Pemerintah telah berupaya untuk melakukan Pembinaan Pasar Rakyat Teratai Higienis Madani Kecamatan Senapelan Kota Pekanbaru, walaupun saat ini pemerintah belum mendapatkan sumber alternatif pendanaan untuk proses renovasi pasar, namun dari sisi lain pemerintah senantiasa berupaya untuk meningkatkan kompetensi pedagang dan pengelola melalui pelatihan yang dilaksanakan demi terciptanya perilaku hidup bersih dan sehat baik untuk pedagang dan pekerja, pengunjung maupun pengelola yakni dengan melaksanakan konsep pembangunan sesuai dengan Pasar Sehat. mengenai Lokasi, Bangunan, Perilaku hidup bersih dan sehat, Keamanan dan Fasilitas Lain. Sehingga dapat dikatakan bahwa dari segi pembinaan, sudah melaksanakan Peraturan Daerah Kota Pekanbaru Nomor 09 Tahun 2014.

Sedangkan untuk Implementasi Peraturan Daerah Kota Pekanbaru Nomor 09 Tahun 2014, dilihat dari sisi pembinaan maka dapat diambil kesimpulan bahwa pada dasarnya Pemerintah daerah telah mengacu kepada Peraturan Daerah tersebut hal ini bisa terlihat dari konsep penataan pedagang, yang mana pemerintah membuat konsep untuk seluruh pedagang agar dapat menempati los atau kios yang ada di dalam Pasar Rakyat Teratai Higienis Madani. Selain itu Pemerintah Daerah sudah melakukan sosialisasi serta pemantauan dan evaluasi pelaksanaan pengelolaan dan pemberdayaan pasar rakyat, agar sesuai dengan Peraturan Daerah Nomor 09 Tahun 2014. 


\section{Pengawasan}

Pengawasan adalah upaya yang dilakukan oleh pemerintah daerah untuk mengawasi keberadaan pasar rakyat dan pendirian pusat perbelanjaan dan toko swalayan. Berdasarkan hasil wawancara dan pengamatan yang dilakukan dapat diambil kesimpulan bahwa dari segi pengawasan pemerintah belum mengawasi secara penuh sebab, selama masa uji coba Pasar Rakyat Teratai Higienis Madani Kecamatan Senapelan di Kota pekanbaru, Dinas Perindustrian dan Perdagangan Kota Pekanbaru yang seharusnya melakukan pengawasan secara berdampingan dengan Dinas Kesehatan Kota Pekanbaru itu belum turun lapangan karena belum adanya surat pemberitahuan untuk melakukan pengawasan.

Sedangkan untuk Implementasi dari segi Pengawasan sebagian sudah dilakukan oleh Pemerintah Daerah melalui kerjasama dengan organisasi terkait, yakni salah satunya adalah dengan Satpol PP dan Ketua Pemuda Setempat, serta dilakukan pengawasan tidak langsung untuk pemungutan retribusi pasar melalui kartu smart yang bekerjasama dengan pihak perbankan. Namun, hasil dari pengawasan belum ada dilaporkan kepada walikota dan DPRD mengingat bahwa belum optimalnya operasional pasar, karena proses renovasi pasar sampai saat ini masih berlangsung. Sehingga dapat dikatakan bahwa pengawasan yang dilakukan saat ini belum melaksanakan secara penuh akan tetapi menuju pelaksanaan yang sempurna untuk Peraturan Daerah Nomor 09 tahun 2014. Sehingga secara langsung sudah diketahui bahwa Implementasi Perda Nomor 09 tahun 2014 juga belum terlaksana secara optimal, karena belum beroperasinya pasar secara efektif.

\section{Kendala-kendala dalam Implementasi Peraturan Daerah No. 09 Tahun 2014 Penataan}

Dalam melaksanakan penataan, Kendala yang dihadapi oleh pemerintah daerah untuk mengatur dan menata keberadaan dan pendirian Pasar Rakyat salah satunya adalah lokasi pasar yang terbatas, karena hanya menggunakan gedung bekas SDN 019. Yang diketahui luas tanah atau area pasar sangat terbatas, sehingga konsep madani yang diharapkan dapat diterapkan di Pasar Higienis tidak akan terlaksana sebagaimana mestinya. Sebab seperti yang kita ketahui bersama bahwa konsep madani yang diinginkan adalah bagaimana transaksi dilakukan dengan mengacu kepada syariat Islam. Tidak mungkin rasanya dengan lokasi yang sempit, akan tercipta konsep madani. Seperti tidak bersinggungan antara pembeli wanita dengan pembeli laki-laki.

Selain itu pemerintah daerah merasakan sulitnya menertibkan Pedagang Kaki Lima karena ketika dilakukan uji coba pasar, tidak seluruh pedagang bersedia untuk masuk ke dalam pasar. Sehingga hal ini menimbulkan kebiasaan yang buruk dari masyarakat yakni Masyarakat terbiasa melaksanakan transaksi jual beli dengan menggunakan kendaraannya tanpa harus berjalan jauh dan bayar parkir, yang secara langsung mengakibatkan pedagang yang berjualan di dalam Pasar Rakyat Teratai Higienis Madani menjadi sepi pelanggan. Jika hal ini terus berlangsung sampai selesai proses renovasi, maka untuk mewujudkan Peraturan Daerah Nomor 09 Tahun 2014 tidak terimplementasi.

\section{Pemberdayaan}

Adapun kendala yang dihadapi Pemerintah dari segi pemberdayaan adalah dalam hal peningkatan disiplin pedagang dan pembeli, yang mana diketahui bahwa pedagang sangat sulit ditertibkan. Hal ini terlihat ketika dilakukan uji coba pasar, pedagang tidak mau mengikuti aturan pemerintah daerah yang mewajibkan berjualan di dalam pasar, dengan dalih los atau kios yang tidak mencukupi, sehingga pemerintah daerah melakukan renovasi gedung untuk menambah kapasitas pedagang yang akan berjualan di dalam los atau kios.

Begitu pula untuk pembeli yang tidak mau masuk ke dalam pasar untuk berbelanja karena adanya persepsi masyarakat bahwa semakin bagus pasarnya maka akan semakin mahal barang -barang yang dijual, padahal, asumsi ini sudah jelas salah. Di mana bahwa Pasar Sehat Higienis Madani Kecamatan 
Senapelan Kota Pekanbaru berdiri bertujuan untuk membantu masyarakat agar terhindar dari segala macam penyakit, karena kebanyakan penyakit menular yang menyebar di masyarakat terjadi karena kondisi pasar yang tidak sehat.

Selain itu, untuk meningkatkan kualitas dan pembenahan sarana fisik, pemerintah menemukan kendala di mana sarana fisik yang sudah disediakan (ketika dilakukan uji coba pasar) hanya bertahan beberapa hari saja, hal ini terjadi karena pedagang belum terbiasa untuk memelihara atau merawat dan menggunakan sarana prasana dengan baik yang sesuai dengan aturan yang berlaku. Bahkan ada sebagian dari pedagang yang menyalahgunakan sarana fisik tersebut untuk kepentingan pribadi sehingga menyebabkan kerugian yang sangat besar, yakni hilangnya semua sarana dan prasarana yang sudah disediakan oleh pemerintah. Hal ini tentu saja menghambat Implementasi Peraturan Daerah Nomor 09 Tahun 2014.

\section{Pembinaan}

Adapun kendala yang dihadapi oleh Pemerintah Daerah dari segi Pembinaan adalah sulitnya mendapatkan sumber pendanaan alternatif untuk pemberdayaan pasar dan pembinaan untuk peningkatan kompetensi pedagang, terutama dalam kondisi perekonomian saat ini, di mana dilakukan pemangkasan anggaran untuk beberapa kegiatan dalam suatu institusi. Sehingga hal ini berdampak langsung untuk penyelenggaraan Pasar Sehat.

Selain itu, kegiatan sosialisasi kebijakan pengelolaan dan pemberdayaan pasar rakyat, dirasakan pemerintah daerah tidak mendapatkan imbal balik, di mana kegiatan sosialisasi yang dilakukan dalam rangka meningkatkan kompetensi pengelola dan pedagang. Justru belum terlaksana sebagaimana mestinya, karena peserta yang mengikuti sosialisasi justru merasa bahwa ilmu yang mereka miliki lebih bagus dibandingkan dengan materi sosialisasi. Hal ini terjadi karena pengelola dan pedagang merasa bahwa pengalaman yang mereka miliki sudah banyak sehingga mereka merasa sudah profesional di bidangnya. Hal ini tentu saja menjadi kendala dalam Implementasi Peraturan Daerah Nomor 09 Tahun 2014. Yang pada dasarnya menginginkan adanya kegiatan sosialisasi dalam pelaksanaan pasar sehat.

\section{Pengawasan}

Walaupun pengawasan saat ini sudah melalui kerjasama dengan instansi terkait, organisasi masyarakat, bahkan masyarakat yang berada di lingkungan setempat, namun, tetap saja pemerintah menemukan kendala dalam pelaksanaannya, yakni masyarakat yang mempunyai kios atau los sering tidak menggunakan kiosnya tetapi disewakan kepada pedagang lain dengan harga sewa yang mahal. Hal ini tentu saja tidak sesuai dengan keinginan pemerintah dalam hal pengelolaan pasar sehat, yang mengacu pada Peraturan Daerah Nomor 09 Tahun 2014. Dimana pemerintah menginginkan seluruh pedagang untuk berjualan di dalam pasar tanpa adanya biaya sewa los atau kios, melainkan hanya retribusi yang nilainya terjangkau oleh pedagang atau masyarakat yang berjualan di pasar. Pemerintah tidak menginginkan adanya pemilik yang curang dalam menggunakan fasilitas yang sudah disediakan oleh Pemerintah Daerah dengan menyewakannya kepada pihak lain.

Kendala lain yang ditemui oleh pemerintah daerah yakni belum adanya inpeksi langsung yang dilakukan oleh Dinas Kesehatan Kota Pekanbaru. Pemerintah mewajibkan adanya inpeksi langsung tersebut untuk mengontrol kegiatan pasar, apakah beroperasi sesuai aturan pasar sehat atau tidak. Dengan kata lain, belum ada pengawasan dari Dinas Kesehatan Kota Pekanbaru.

Selain itu Kegiatan pengawasan yang dilakukan oleh instansi terkait juga belum dilaporkan kepada walikota maupun DPRD, Sehingga terjadi kesulitan untuk pengukuran Implementasi Peraturan Daerah Nomor 09 Tahun 2014. Hal ini terjadi akibat belum rampungnya proses renovasi Pasar Rakyat Teratai Higienis Madani Kecamatan Senapelan di Kota Pekanbaru. 


\section{SIMPULAN}

1. Implementasi Peraturan Daerah Nomor 09 Tahun 2014 yang diukur dari penataan, pemberdayaan, pembinaan, dan pengawasan dapat diambil kesimpulan bahwa:

a. Penataan: Pasar Rakyat Teratai Higienis Madani Kecamatan Senapelan di Kota Pekanbaru telah sesuai dengan Peraturan Daerah Nomor 09 Tahun 2014 yakni segi penentuan lokasi sudah sesuai dengan Rencana Umum Tata Ruang Setempat. Secara Umum sudah dilakukan penataan Ruang Kantor Pengelola, penataan ruang dagang, penataan tempat penjualan bahan pangan dan makanan, penataan area parkir, kontruksi, tangga, ventilasi, pintu serta sudah terdapat pencahayaan yang cukup baik di dalam pasar (hal ini terlihat dari pembangunan yang saat ini sedang berlangsung). Selain itu dalam hal sanitasi, di dalam Pasar Rakyat Teratai Higienis Madani Kecamatan Senapelan di Kota Pekanbaru. Sudah dirancang untuk penyediaan air bersih, kamar mandi dan toilet, bagian pengelola sampah, Drainase, Tempat Cuci Tangan, serta apabila sudah resmi beroperasi akan di check secara berkala kualitas makanan dan bahan pangan yang di jual di pasar.

b. Pemberdayaan: Pasar rakyat Teratai Higienis Madani Kecamatan Senapelan di Kota Pekanbaru telah sesuai dengan Peraturan Daerah Nomor 09 Tahun 2014 yakni sudah berdasarkan visi dan misi, mengadakan pelatihan khusus kepada pengelola yakni dalam hal pelatihan untuk menjaga kebersihan dan keamanan pasar, agar tetap higienis dan cara mengelola pedagang agar berjualan dengan tertib dalam kios. Pemerintah daerah telah berupaya melindungi Pasar Rakyat agar tetap eksis dan mampu berkembang menjadi suatu usaha yang lebih berkualitas, baik dari aspek manajemen, maupun fisik atau tempat agar dapat bersinergi dengan pusat perbelanjaan dan toko swalayan. c. Pembinaan: Pasar rakyat Teratai Higienis Madani Kecamatan Senapelan di Kota Pekanbaru telah mengacu kepada Peraturan Daerah Nomor 09 Tahun 2014 meskipun pemerintah daerah belum mendapatkan sumber alternatif pendanaan, akan tetapi Pemerintah telah mengadakan pelatihan dalam rangka meningkatkan kompetensi pedagang dan pengelola pasar, telah memprioritaskan pedagang untuk mendapatkan kios, telah dilakukan sosialisasi untuk pemberdayaan pasar rakyat.

d. Pengawasan: Pasar Rakyat Teratai Higienis Madani Kecamatan Senapelan di Kota Pekanbaru belum mengacu kepada Peraturan Daerah Nomor 09 Tahun 2014, selama masa uji coba pasar rakyat teratai higienis madani kota Pekanbaru, Dinas Kesehatan Kota Pekanbaru belum pernah melaksanakan inspeksi langsung, sehingga Dinas Kesehatan Kota Pekanbaru belum dapat menilai konsep dari pelaksanaan pasar rakyat teratai higienis madani kota Pekanbaru.

2. Kendala-Kendala yang dihadapi Pemerintah Daerah dalam Implementasi Peraturan Daerah Nomor 09 Tahun 2014 yang diukur dari penataan, pemberdayaan, pembinaan, dan pengawasan adalah sebagai berikut:

a. Penataan: Meskipun dari sisi penataan pemerintah daerah telah berupaya untuk melakukan penataan sesuai dengan Implementasi Peraturan Daerah Nomor 09 Tahun 2014 namun, pada dasarnya dalam penentuan lokasi, terdapat kesulitan penataan tata ruang karena sempitnya lokasi Pasar, yang mana sebagaimana diketahui bahwa Lokasi yang saat ini direnovasi adalah bekas gedung SDN 019 yang luas tanahnya juga kecil, sehingga penataan menjadi sulit dilakukan.

b. Pemberdayaan: Dalam melakukan pemberdayaan pemerintah mengalami kendala dalam Implelementasi Peraturan Daerah Nomor 09 Tahun 2014 yakni, sulitnya melakukan pembinaan disiplin kepada para pedagang dalam rangka 
melaksanakan pemberdayaan untuk peningkatan kompetentensi pedagang, di mana pemerintah merasakan kesulitan yang teramat luar biasa dalam menertibkan pedagang kaki lima, karena pada saat uji coba pasar ditemukan fakta di mana tidak seluruh pedagang bersedia masuk untuk berjualan di pasar teratai higienis madani.

c. Pembinaan: Dalam melakukan pembinaan, Pemerintah daerah mengalami kendala dalam Implelementasi Peraturan Daerah Nomor 09 Tahun 2014 yakni, sulitnya mendapatkan sumber alternatif pendanaan, sehingga memperlambat proses operasional pasar. Serta tidak efektifnya hasil sosialisasi yang dilakukan dalam rangka memperbaiki kebijakan pengelolaan dan Pemberdayaan Pasar Rakyat Teratai Higienis Madani, sehingga kesulitan untuk mengatasi perilaku pedagang dan pembeli sampai saat ini.

d. Pengawasan: Dalam melakukan pengawasan, Pemerintah daerah mengalami kendala dalam Implelementasi Peraturan Daerah Nomor 09 Tahun 2014 yakni, tidak efektifnya pengawasan yang dilakukan. Hal ini bisa terlihat dari adanya masyarakat yang mempunyai kios atau los sering tidak menggunakan los atau kiosnya tetapi disewakan kepada pedagang lain dengan harga sewa yang mahal.

\section{DAFTAR PUSTAKA}

Agustinus, Leo. 2006. Politik dan Kebijakan Publik. Bandung : AIPI

A Ubaedillah, dkk. 2010. Pendidikan Kewarganegaraan, Demokrasi, Hak Asasi Manusia, dan Masyarakat Madani. Jakarta: ICCE UIN Syarif Hidayatullah Jakarta bekerjasama dengan Prenada Media Group.

Abdul Wahab, Solichin. 2012. Analisis Kebijakan:Dari Formulasi Ke Penyusunan Model-Model Implementasi Kebijakan Publik. Jakarta: Bumi Aksara

Danel Alexander S. Turnip, 2015, Evaluasi Pengelolaan Pasar Tradisional di Pasar Minggu Kecamatan Meliau Kabupaten Sanggu.

Junisa Ginas Sirvia. 2017.Analisa Penyelenggaraan Pasar Higienis Madani Kota Pekanbaru

Pasolong, Herbani. 2014. Teori Administrasi Publik, Bandung : Alfabeta.

Kumiawan, Agung 2005. Transformasi Pelayanan Publik. Yogyakarta: Pembaharuan.

Saprul Sinaga, 2015. Pengelolaan Pasar Kaget oleh Dinas Pasar Kota Pekanbaru di Kecamatan Sail

Winarno, Budi. 2005. Teori dan Proses Kebijakan Publik, Yogyakarta: Media Pressindo.

Widodo, Joko. 2010. Analisis Kebijakan Publik. Malang: Bayumedia.

Zuriah, Nurul. 2009. Metode Penelitian Sosial dan Pendidikan, Jakarta: Bumi Aksara. 